\title{
Pengelolaan Wakaf Produktif di Kuwait Pembelajaran bagi Pengembangan Wakaf di Indonesia
}

\author{
Siska $^{1^{*}}$
}

\section{INFO ARTIKEL}

\section{Penulis:}

${ }^{1}$ Fakultas Ekonomi, Universitas Islam Riau, Pekanbaru, Indonesia

*E-mail: siska@eco.uir.ac.id

\section{Untuk mengutip artikel ini:}

Siska 2018, 'Pengelolaan wakaf produktif di kuwait pembelajaran bagi pengembangan wakaf di indonesia', Jurnal Ekonomi KIAT, vol. 30 , no. 1, hal. 1-11.

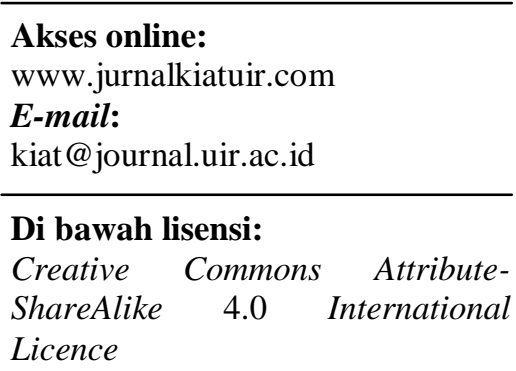

\begin{abstract}
ABSTRAK
Waqf is one of the ways of distributing welfare to the community. The continuity of the benefits of waqf is made possible by the enactment of the types of productive waqf established to support religious activities, compensation, education and public facilities. Implementation of waqf in Indonesia especially productive waqf still faces various obstacles. Various waqf practices in other countries that are considered successful in managing productive waqf need to be a lesson for Indonesia, one of which is the application of productive waqf in Kuwait. This study is a theoretical study of productive waqf as well as a case study of the application of productive waqf in Kuwait which is considered successful. The development of waqf in Kuwait has passed a long stage (seven stages) from waqf management by the community (pre-1921 AD) until the SekjendWakaf (pre-1993 M). The types of waqf in Kuait are also very diverse such as health endowments, water, public, investment endowments and so on. Kuwait has also implemented very good waqf governance with the establishment of the Awqaf Public Foundation (KAPF) in 1993. The existence of the KAPF is very influential on the development of waqf in Kuwait. The increase in waqf income for 16 years has tripled. Likewise with the development of capital assets, there is a very significant increase.
\end{abstract}

Katakunci: Produvtive Waqf, Awqaf Public Foundation (KAPF)

\section{Pendahuluan}

Berdasarkan data Badan Pusat Statistik (BPS) per September 2018 jumlah penduduk miskin di Indonesia mencapai 25,67 juta orang atau sebesar 9,66\% dari jumlah penduduk Indonesia dengan menggunakan garis kemiskinan sebesar Rp 410.670. Begitu juga dengan angka ketimpangan pengeluaran penduduk Indonesia (Gini Rasio) pada September 2018 sebesar 0,384 mengalami penurunan 0.005 point dari Maret 2018 dan 0,007 point dari September 2017 (https://www.bps.go.id). Data ini menunjukkan bahwa tujuan negara mewujudkan kesejahteraan bagi seluruh rakyat masih merupakan pekerjaan rumah bagi bangsa Indonesia. Berbagai upaya telah dilakukan pemerintah untuk mengatasi masalah ini dengan berbagai program pembangunan. Apabila dilihat dari komposisi penduduk berdasarkan agama, maka lebih dari $85 \%$ penduduk Indonesia beragama Islam. Tentunya penduduk Muslim yang besar tersebut sangat diharapkan perannya dalam menyelesaikan masalah kemiskinan di Indonesia dan mewujudkan kesejahteraan. Dalam ekonomi Islam pendistribusian kesejahteraan kepada masyarakat dapat dilakukan melalui peran zakat, infaq dan wakaf.

Sepanjang sejarah Islam, berbagai kebutuhan dan dan pelayanan dasar dan umum untuk masyarakat dibiayai dari dana wakaf. Wakaf mengalami kemajuan pesat selama abad ke 9 dan 10 Masehi. Kemanjuan ini ditandai dengan berkembangnya jenis-jenis wakaf baru seiring dengan meluas dan makin kompleksnya kebutuhan social dan ekonomi masyarakat muslim yang bercorak urban. Pelayanan-pelayanan yang diberikan oleh wakaf tidak lagi bersifat keagamaan dan santunan semata, tetapi mencakup sarana sarana publik, seperti jalan, jembatan, rumah sakit dan madrasah. Kesinambungan manfaat wakaf tersebut, dimungkinkan oleh berlakunya jenis wakaf produktif yang didirikan untuk menopang kegiatan keagamaan, santunan, pendidikan, dan sarana publik. Wakaf produktif biasanya berupa tanah tanah pertanian atau perkebunan dan gedung gedung komersial, dikelola sedemikian rupa sehingga mendatangkan keuntungan yang sebagainnya disisihkan untuk mendanai pelayanan pelayanan sosial keagamaan atau untuk didermakan kepada penerima yang telah ditentukan (Tuty A Najib, dkk; 2006; 73).

UU No. 41 tahun 2004 tentang wakaf memberikan dasar hukum terhadap wakaf produktif di Indonesia. Pada pasal 16 ayat (1) disebutkan bahwa harta benda wakaf terdiri dari: benda tidak bergerak dan benda bergerak. Sedangkan pada ayat (2) disebutkan bahwa benda tidak bergerak sebagaimana dimaksud pada ayat (1) huruf A meliputi: Hak atas tanah sesuai dengan ketentuan 
peraturan perundang undangan yang berlaku baik yang sudah maupun belum terdaftar, bangunan atau bagian bangunan yang berdiri di atas tanah sebagaimana dimaksud pada huruf $\mathrm{A}$, tanaman atau benda lain yang berkaitan dengan tanah, hak milik atas satuan rumah susun sesuai dengan ketentuan peraturan perundang udangan yang berlaku, benda tidak bergerak lain sesuai dengan ketentuan syariah dan peraturan perundang-undangan berlaku. Sedangkan yang dimaksud benda bergerak adalah harta benda yang tidak bisa habis karena dikonsumsi, yang meliputi uang, logam mulia, surat berharga, kendaraan, haka atas kekayaan intelektual, hak sewa, benda bergerak lain sesuai dengan ketentuan syariah dan peraturan perundang-undangan yang berlaku. Dengan adanya UU No. 41 ini diharapkan paradigma lama tentang wakaf yang hanya meliputi Mesjid, sekolah dan kuburan bisa berubah dan dapat memberikan kontribusi maksimal bagi kesejahteraan masyarakat. Menurut Kepala Divisi Pengelolaan \& Pemberdayaan BWI, Iwan Agustiawan Fuad potensi wakaf di Indonesia bisa mencapai Rp 180 triliun, sedangkan tahun 2017 total dana penghimpun wakaf sebesar Rp 400 miliar (http://mysharing.co).

Penerapan wakaf di Indonesia masih menghadap beberapa kendala, Huda, dkk (2017) dalam penelitiannya menemukan beberapa permasalahan utama pengelolaan wakaf di Indonesia serta memberikan beberapa solusi alternatif. Hasil penelitian menunjukkan bahwa masalah wakaf prioritas di Indonesia terletak pada aspek Nazhir yang bukan profesi utama (kerja sampingan). Masalah kedua adalah bahwa peraturan mengenai wakaf yang sudah disahkan tidak cukup disosialisasikan yang menyebabkan kurangnya pengetahuan tentang wakif dan itu merupakan masalah ketiga. Solusi utama untuk masalah nazhir menurut Huda, dkk (2017) adalah mengubah nazhir individual menjadi nazhir institusi, dan solusi untuk masalah regulator adalah menciptakan hubungan harmonis antara dakwah institusi. Ekspansi dan inovasi dalam manajemen wakaf adalah solusi untuk masalah strategi.

Menurut Rusydiana dan Abrista Devi (2017), terdapat beberapa kendala dalam penerapan wakaf uang di indonesia diantaranya: a) masalah sumber daya manusia,yang meliputi: lemahnya kualitas kerja pengelola dana, kurangnya wawasan tentang wakaf, adanya penyelewengan atas dana wakaf, dan personal interest dalam pengelolaan dana; b) masalah kepercayaan (trust) yang meliputi: produk wakaf tunai tidak menjadi prioritas, lemahnya kepercayaan donator, dominasi oleh yayasan individu, penerima wakaf yang kurang amanah; c) masalah sistem terdiri dari lemahnya UU perwakafan, lemahnya sistem informasi wakaf, kurangnya database wakaf yang valid, dan lemahnya sistem tata kelola; d) dan masalah syariah terdiri dari tidak adanya pengawas syariah, perdebatan akad wakaf tunai, tidak terpenuhinya akad tunai, penamaan dana tabarru' menjadi dana wakaf.

Dari beberapa penelitian mengenai beberapa permasalahan wakaf di Indonesia dapat dipahami bahwa Indonesia perlu untuk terus memperbaiki pengelolaan wakaf khususnya wakaf produktif di Indonesia. Berbagai praktek wakaf di negara-negara lain yang terbilang sukses dalam mengelola wakaf produktif perlu menjadi pembelajaran bagi Indonesia. Sebagai contoh adalah pengelolaan wakaf di negara Kuwait. Lembaga pemerintah yang yang berwenang mengurus aset-aset wakaf di Kuwait ialah Kuwait Awqaf Public Foundation (KAPF) yang terbentuk sejak tahun 1993. Menurut Al Osman (1997) dalam Muljawan, Raditya, dan Diana Yumanita (2016), KAPF telah menjalankan perannya dengan sangat baik sebagai operator aset-aset wakaf di Kuwait, sehingga Organisasi Konferensi Islam (OKI) menunjuk Kuwait menjadi koordinator bagi lembagalembaga wakaf di dunia Islam. Paper ini akan menguraikan lebih rinci praktek pengelolaan wakaf produktif Kuwait.

\section{Telaah Pustaka}

\subsection{Pengertian dan jenis wakaf}

Kata wakaf berasal dari kata kerja waqafa yang berarti menghentikan, berdiam di tempat atau menahan sesuatu. Dalam Fiqh sunnah, Sayyid Sabiq (1987: 45-46) menyatakan, wakaf adalah menahan sesuatu benda yang kekal zatnya, dan memungkinkan untuk diambil manfaatnya guna diberikan dijalan kebaikan. Dalam bahasa yang lain, wakaf dapat diartikan menahan suatu benda untuk diambil manfaatnya sesuai dengan ajaran Islam (Ali, 2012: 80).

Meskipun terdapat perbedaan pendapat para ulama dalam memaknai wakaf, namun, konsep wakaf ini dapat didasarkan pada keumuman ayat-ayat al Qur'an yang menjelaskan infaq fi sabilillah. Diantara ayat ayat tersebut antara lain Quran surat Al Baqarah ayat 267 yang artinya:

"Hai orang-orang yang beriman, nafkahkanlah (di jalan Allah) sebagian dari hasil usahamu yang baik-baik dan sebagian dari apa yang kami kelurkan dari bumi untuk kamu. Dan janganlah kamu memilih yang buruk buruk lalu kamu menafkahkan daripadanya padahal kamu sendiri tidak mau mengambilnya melainkan dengan memicingkan mata terhadapnya. Dan ketahuilah allah maha kaya lagi maha terpuji" (Al Baqarah ayat 267).

Didalam ayat ke 261 Surat Al Baqarah Allah SWT mengambarkan ganjaran yang besar bagi orang yang menafkahkan hartanya di jalan Allah,

"Perumpamaan (nafkah yang dikeluarkan oleh) orang-orang yang menafkahkan hartanya di jalan Allah adalah serupa dengan sebutir benih yang menumbuhkan tujuh bulir. Pada tiap-tiap bulir 
menghasilkan seratus biji. Allah melipat gandakan (ganjaran) bagi siapa-siapa yang dia kehendaki, dan Alla Maha Luas karunia-Nya) lagi Maha Mengetahui". (Al Baqarah ayat: 261)

Sedangkan diantara hadis yang menjadi dalil wakaf adalah hadist yang menceritakan tentang kisah Umar bin Al Khaththab ketika memperoleh tanah di Khaibar. Setelah ia meminta petunjuk Nabi tentang tanah tersebut, Nabi menganjurkan untuk menahan asal tanah dan menyedekahkan hasilnya.

Bahwa sahabat Umar ra memperoleh sebidang tanah di Khaibar, kemudian Umar ra menghadap Rasulullah untuk meminta petunjuk, Umar berkata: "Hai Rasulullah salallahu álaihi wassalam, saya mendapat sebidang tanah di Khaibar, saya belum mendapat harta sebaik itu, maka apakah yang engkau perintahkan kepadku?" Rasulullah bersabda: "Bila engkau suka, kau tahan (pokoknya) tanah itu, dan engkau sedekahkan (hasilnya), tidak dijual, tidak dihibahkan, dan tidak diwariskan". "Ibnu Umar berkata: "Umar menyedekahkannya (hasil pengelolaan tanahnya) kepada orang orang fakir, kaum kerabat, hamba sahaya, sabilillah, ibnu sabil dan tamu. Dan tidak dilarang bagi yang mengelola (nazir) wakaf makan dari hasilnya dengan cara yang baik (sepantasnya) atau memberi makan orang lain dengan tidak bermaksud menumpuk harta" (HR Bukhari, Kitab Usysyurut, No 2532).

Hadis lain yang menjelaskan tentang wakaf diantaranya adalah Hadis yang diriwayatkan oleh Imam Muslim dari Abu Hurairah yang artinya; "Apabila seorang manusia itu meninggal dunia, maka terputuslah amal perbuatannya kecuali tiga sumber yaitu sedekah jariah (wakaf), ilmu pengetahuan yang bisa diambil manfaatnya, dan anak sholeh yang mendoakannya."

Sementara menurut UU Nomor 41 Tahun 2004 Pasal 1 wakaf adalah perbuatan hukum wakif untuk memisahkan dan atau menyerahkan sebagian harta benda miliknya untuk dimanfatkan selamanya atau untuk jangka waktu tertentu sesuai dengan kepentingannya guna keperluan ibadah atau kesejahteraan umum menurut syariah. Dari beberapa definisi wakaf tersebut dapat diambil substansi dari wakaf adalah adanya kemanfatan yang dapat diambil dalam waktu yang lama dengan tidak mengurangi pokok harta yang diwakafkan.

\subsection{Jenis-jenis wakaf}

Wakaf berdasarkan tujuan ada tiga, yaitu:

1) Wakaf sosial untuk kebaikan masyarakat (khairi), yaitu apabila tujuan wakafnya untuk kepentingan umum

2) Wakaf keluarga (dzurri), yaitu apabila tujuan wakaf untuk member manfaat kepada wakif, keluarganya, keturunannya, dan orang-orang tertentu, tanpa melihat kaya atau miskin, sakit atau sehat dan tua atau muda.
3) Wakaf gabungan (musytarak), yaitu apabila tujuan wakafnya untuk umum dan keluarga secara bersamaan.

Wakaf berdasarkan batasan waktunya terbagi menjadi dua macam, yaitu:

1) Wakaf abadi yaitu apabila wakafnya berbentuk barang yang bersifat abadi, seperti tanah dan bangunan dengan tanahnya, atau barang bergerak yang ditentukan oleh wakif sebagai wakaf abadi dan produktif, dimana sebagian hasilnya untuk disalurkan sesuai tujuan wakaf, sedangkan sisanya untuk biaya perawatan wakaf dan mengganati kerusakannya.

2) Wakaf Sementara yaitu apabila barang yang diwakafkan berupa barang-barang yang mudah rusak ketika dipergunakan tanpa member syarat untuk mengganti bagian yang rusak. Wakaf sementara juga bisa dikarenakan oleh keinginan wakif yang member batasan waktu ketika mewakafkan barangnya.

Wakaf berdasarkan penggunaanya dibagi menjadi dua macam, yaitu:

1) Wakaf langsung yaitu wakaf yang pokok barangnya digunakan untuk mencapai tujuannya seperti mesjid untuk shalat, sekolah untuk kegiatan belajar mengajar, rumah sakit untuk mengobati orang sakit dan sebagainya.

2) Wakaf Produktif yaitu wakaf yang pokok barangnya digunakan untuk kegiatan produksi dan hasilnya diberikan sesuai dengan tujuan wakaf.

Di dalam UU Wakaf, harta benda wakaf dapat diklasifikasikan sebagai berikut:

1) Benda tidak bergerak yang meliputi:

a. Hak atas tanah sesuai dengan ketentuan peraturan perundang-undangan yang berlaku baik yang sudah maupun yang belum terdaftar;

b. Bangunan atau bagian bangunan yang berdiri di atas tanah sebagaimana dimaksud pada huruf a;

c. Tanaman dan benda lain yang berkaitan dengan tanah;

d. Hak milik atas satuan rumah susun sesuai dengan ketentuan peraturan perundang undangan yang berlaku;

e. Benda tidak bergerak lain sesuai dengan ketentuan syariah dan peraturan perundangundangan yang berlaku.

2) Benda Bergerak meliputi:

a. Uang;

b. Logam mulia;

c. Surat berharga;

d. Kendaraan;

e. Hak atas kekayaan intelektual;

f. Hak sewa dan;

g. Benda bergerak lain sesuai dengan ketentuan syariah dan perturan perundang undangan yang berlaku. 
Sedangkan wakaf produktif merupakan pengembangan dari paradigma wakaf selama ini yang memadang wakaf hanya sebatas tanah atau tempat ibadah. Wakaf produktif adalah sebuah skema pengelolaan donasi wakaf dari umat, yaitu dengan memproduktifkan donasi tersebut, hingga mampu menghasilkan surplus yang berkelanjutan. Donasi wakaf dapat berupa benda bergerak, seperti uang dan logam mulia, maupun benda tidak bergerak, seperti tanah dan bangunan. Surplus wakaf produktif inilah yang menjadi sumber dana abadi bagi pembiayaan kebutuhan umat, seperti pembiayaan pendidikan dan pelayanan kesehatan yang berkualitas. (Depag RI: 2008). Jika dikaitkan dengan definisi wakaf maka pada dasarnya wakaf adalah produktif, karena dengan produktifitas wakaf tersebut wakaf akan memberikan manfaat yang optimal bagi pembiayaan kebutuhan umat.

Perbedaan antara wakaf langsung dan wakaf produktif terletak pada pola manajemen dan cara pelestarian wakaf. Wakaf langsung membutuhkan biaya perawatan yang dananya diperoleh dari luar benda wakaf. Misalnya seseorang yang mewakafkan satu unit bangunan untuk komplek pendidikan atau madrasah, masih membutuhkan biaaya operasional, misalnya untuk menggaji guru, kebutuhan kantor, perawatan gedung dan kebutuhan-kebutuhan lainnya. Sedangkan wakaf produktif hasilnya dapat digunakan untuk melestarikan benda wakaf dan selebihnya dibagikan kepada mustahik wakaf sesuai kehendak wakif (Aula, 2012).

\subsection{Rukun wakaf}

Adapun rukun wakaf menurut ulama Hanafiyah hanya Sighah (ikrar atau akad) saja. Adapun sebagian besar ulama Malikiyah, Syafi'iyah, Zaidiyah, dan Hanabilah berpendapat bahwa rukun wakaf ada empat, yaitu: 1) al-Wakif (orang yang berwakaf); 2) al-Mauquf 'alaih (tujuan atau tempat wakaf); 3) alMal al-Mauquf (harta yang diwakafkan); 4) alSighah (ikrar atau akad), (al Kabisi, 1977: 147). Berikut ini akan dijelaskan masing-masing rukun wakaf sebagai berikut:

1) al-Wakif (orang yang berwakaf). Seorang wakif haruslah memenuhi syarat haruslah memenuhi syarat diantaranya: kecakapan bertindak, telah dapat mempertimbangkan baik buruknya perbuatan yang dilakukan dan benar-benar pemilik harta yang diwakafkan.

2) al-Mauquf 'alaih (tujuan atau tempat wakaf), yang berhak menerima hasil wakaf apakah untuk kepentingan umum, untuk menolong fakir miskin, untuk kepentingan anggota keluarga sendiri. Namun yang lebih baik adalah kalau tujuan wakaf itu jelas diperuntukkan bagi kepentingan umum, kemaslahatan masyarakat (Rachmad, 1964 dalam Ali, 2012).

3) al-Mal al-Mauquf (harta yang diwakafkan). Harta yang diwakafkan menurut Ali (2012) haruslah memenuhi syarat: Pertama, harus tetap zatnya dan dapat dimanfatkan untuk jangka waktu yang lama, pemanfatan nya haruslah untuk hal hal yang berguna, halal dan sah menurut hokum; Kedua, harta yang diwakafkan hendaklah jelas wujudnya dan pasti batas batasnya (jika berbentuk tanah); Ketiga, harta tersebut betul-betul milik wakif dan bebas dari beban; Keempat, harta tersebut dapat berupa benda dapat juga benda bergerak.

Anshori (2005:25) menambahkan dengan nazhir (pengelola wakaf) dan jangka waktu yang tidak terbatas. Adapun Khosyi'ah (2010: 53) menambahkan rukun wakaf dengan saksi, tambahan ini sesuai dengan ketentuan dalam perundang-undangan di Indonesia. Ketentuan dari rukun-rukun wakaf tersebut di atas sudah tertulis dari masa sahabat Umar bin Khattab. Wakaf tanah Khaibar ditulis dengan persaksian resmi di atas sebuah kulit, dengan instrumen-instrumen tertentu yang pada akhirnya ditetapkan menjadi rukun wakaf, yaitu waqif, almauquf, nazhir, dan sighah, aujih al-infaq, katib dan syahid (al-Hujaili, 1999: 180-184 dalam Muljawan, Raditya, dan Diana Yumanita, 2016).

\subsection{Dampak wakaf terhadap kesejahteraan sosial}

Sejarah pada zaman sahabat telah mencontohkan bagaimana wakaf bisa memberikan kesejahteraan dari banyak aspek kehidupan masyarakat. Sebut saja kisah bagaimana Utsman Ibn Affan membeli sumur Raumah, lalu digratiskan untuk kepentingan umat. Menumbuh-suburkan kebun kurma, yang berdampak peningkatan kesejahteraan masyarakat. Pohon kurma terus bertambah, hingga diwariskan dari generasi ke generasi. Dari para Khalifah, hingga Daulah Utsmaniyyah, dan terakhir dikelola oleh pemerintah Arab Saudi. Departemen Pertanian Saudi menjual hasil dari ribuan pohon ke pasar-pasar. Setengah keuntungannya disalurkan ke anak yatim. Setengahnya lagi disimpan dalam bentuk rekening di bank atas nama Utsman Ibn Affan, dibawah pengawasan Departemen Pertanian. Uang yang mampir di rekening Ridwanullah Utsman Ibn Affan terus membengkak, hingga pemerintah Saudi memutuskan membelikan tanah dekat Masjid Nabawi atas nama Utsman bin Affan. Dan kini, ribuan tahun berlalu, manfaatnya tak berhenti, terus mengalir. Hotel berbintang atas nama beliau pun berdiri megah, tempat singgah para peziarah. Hasilnya? Tentu untuk kemanfaatan umat yang seluas-luasnya. Tanah tersebut dibangun Hotel bintang lima hasil wakaf Utsman. Hotel milik Utsman bin Affan pun kini berdiri kokoh di samping Masjid Nabi. Peziarah berdatangan menginap di sana, hingga omset hotelnya bisa mencapai puluhan juta per bulan. Setengah keuntungannya lagi-lagi digunakan untuk kegiatan sosial. Setengahnya lagi, disimpan di rekening atas nama Utsman bin Affan. Subhanallah, walau jasad tertimbun tanah, namun amal Utsman bin Affan terus mengalir. Manfaatnya terus dirasakan hingga kini. Hotel dan Rekening atas nama Utsman, 
menjadi saksi kedermawanan sahabat nabi ini. (www.kompasiana.com)

Syaikh, Ismail, et al. (2017) menyatakan bahwa Sebagian besar negara mayoritas Muslim umumnya berpenghasilan rendah, dan pemerintah pada umumnya lemah dalam pengumpulan pajak mereka, tata kelola yang efektif dan kapasitas untuk pengeluaran pembangunan. Lembaga keuangan swasta sebagian besar melayani orang-orang yang dapat memenuhi pinjaman berdasarkan kriteria pendapatan. Dengan demikian, institusi Wakaf dapat mengisi kesenjangan sebagai lembaga keuangan sosial dengan menyediakan layanan intermediasi untuk secara efektif memanfaatkan tabungan sosial abadi. Fleksibilitas dalam aturan wakaf memungkinkannya untuk melayani para penerima manfaat secara langsung atau melalui lembaga keuangan dan menyediakan berbagai macam jasa sosial.

Memang banyak cara yang dapat dilakukan untuk mengatasi masalah kemiskinan, mulai dari tindakan preventif sampai tindakan kuratif. Suatu cara yang penting untuk mengurangi kemiskinan adalah charity (amal sosial), yang telah memainkan peranan dan potensial menjadi cara efektif menyelesaikan masalah kemiskinan. Amal sosial terdiri dari banyak bentuk, akan tetapi amal sosial yang akan bertahan lama adalah amal sosial yang memiliki karakteristik berkesinambungan. Wakaf adalah merupakan amal sosial yang berkesinam-bungan yang ada dalam sistem Islam. (Sadeq, 2002). Dengan demikian kemampuan wakaf dalam menyelesaikan masalah kemiskinan dan mewujudkan kesejahteraan terletak pada produktifitan dari wakaf itu.

\section{Pembahasan}

\subsection{Pengelolaan wakaf produktif di Kuwait}

\subsubsection{Gambaran umum negara Kuwait}

Kuwait adalah negara yang terletak di pesisir Teluk Persia, Timur Tengah. Negara ini berbatasan dengan Arab Saudi di sebelah selatan dan Irak di Utara. Pada tahun tahun 2001 hingga 2009, Kuwait menempati urutan tertinggi dalam Indeks Pembangunan Manusia di seluruh jazirah Arab. Negara Kuwair dibagi menjadi 6 kegubernuran yaitu: 1) kota Kuwait; 2) Al Farwaniyah; 3) Al Asimah; 4) Al Jahra; 5) Hawalli; 6) Mubarak Al Kabeer (https://id.wikipedia.org/wiki /Kuwait).

Berdasarkan data dari Kuwait Public Authority for Civil Information (KPACI) per Juni 2017 (https:// www.kemlu.go.id/kuwaitcity/id) sebanyak 4.437.590 orang, di mana 1.351.955 adalah WN Kuwait $(30,46 \%)$ dan 3.085 .635 orang adalah WN Asing (69,54\%), yang terdiri dari: Arab (1.215.213 orang); Asia (1.781.728 orang); Afrika (48.229 orang); Eropa (16.793 orang); Amerika Utara (20.263 orang); Amerika Selatan (1.738 orang); Australia (1.671 orang).

Bentuk negara Kuwait adalah Monarkhi (Emirat) Konstitusional, sistem pemerintahannya adalah parlementer. Badan politik negara terdiri atas Emir, kabinet dan Dewan Nasional (parlemen). Emir adalah kepala negara. Ia mengangkat dan memberhentikan perdana mentri dan para menteri setelah melakukan konsultasi secara kekeluargaan. Emir juga menentukan pewaris kekuasaan yang harus disetujui oleh mayorotas anggota Dewan nasional. Emir merupakan komandan tertinggi angkatan perang. Pemegang kuasa eksekutif adalah perdana menteri dan kabinet. Sedangkan sistem hukum British common law, French civil law, Egyptian civil law dan hokum Syariah (https://www.kemlu.go.id/kuwait city/id)

\subsubsection{Sejarah perkembangan wakaf di Kuwait}

Proses perkembangan wakaf di Kuwait menurut Thabrani dalam Khalilur Rahman (2015) tidak terlepas dari beberapa tahapan, yaitu:

1) Tahap pertama (manajemen wakaf oleh masyarakat (pra-1921 M))

Perkembangan wakaf di Kuwait dimulai sejak munculnya Negara Kuwait pada zaman kuno, yaitu ketika masyarakat Kuwait membangun masjidmasjid dan mewakafkannya. Bukti bahwa wakaf di Kuwait muncul sejak zaman kuno adalah penemuan Ilmuwan terhadap suatu masjid yang bernama Masjid Ibn Bahr yang didirikan pada tahun 1108 H/1695 M. Sejak saat itu kemudian wakaf berkembang bersamaan dengan perkembangan Negara Kuwait.

Tahap awal ini ditandai dengan adanya pengaturan wakaf secara langsung oleh pemerintah. Sejarah mencatat bahwa salah satu pendapat dari seorang qadhi (hakim) dijadikan panutan dalam melaksanakan proses perwakafan di Kuwait. Qadhi tersebut adalah Syekh Muhammad Ibn Abdullah alAdsani. Seorang qadhi yang memperpanjang masa kerjanya sampai 60 tahun.

Pada masa ini, wakaf ditasharufkan dengan cara yang berbeda sesuai dengan kebutuhan masyarakat dan lingkungan sekitar. Wakaf pada masa itu bermacam-macam bentuknya, di antaranya adalah wakaf toko, rumah, wakaf pohon (kelapa), perikanan dan lain-lain. Pentasarufan wakaf tersebut adalah dari hasil yang didapat yang ditentukan oleh pewakafnya. Kemudian, hasil tersebut kemudian digunakan untuk perawatan masjid, kurban, pekerjaan, membuat jalan-jalan air, pendanaan terhadap penghafalan Al-Quran, sedekah, kesejahteraan masyarakat, bantuan terhadap fakir miskin dan lain-lain yang bersifat umum.

2) Tahap kedua (administrasi pemerintah I (1921 M1948 M))

Sebelum abad ke-20 M, perhatian pemerintah Kuwait hanya berkisar pada pertahanan, keamanan, kegiatan kelautan, administrasi pemerintahan, regulasi perdagangan dan lain-lain. Awal abad ke$20 \mathrm{M}$, perhatian pemerintah Kuwait mulai masuk 
hampir di seluruh aspek kehidupan masyarakat Kuwait pada masa itu terutama pada aspek perekonomian dan masyarakat. Wakaf menjadi salah satu perhatian masyarakat, bukti perhatian pemerintah terhadap wakaf di Kuwait adalah dengan dibentuknya suatu departemen yang secara khusus menangani permasalahan wakaf di Kuwait. Departemen tersebut didirikan pada tahun $1921 \mathrm{M}$. Departemen tersebut secara khusus difungsikan sebagai perancang dan pengontrol sistem wakaf, menjamin perkembangan dan segala aspek yang berhubungan dengan wakaf pada saat itu. Pada tahun 1948 departemen ini memberi tugas untuk mengelola tempat tempat ibadah dan merawat orang-orang yang lemah.

3) Tahap ketiga (administrasi pemerintah II (19491961 M)

Pada tahap ini, pemerintah tidak hanya meletakkan dasar-dasar perwakafan melalui lembaga wakaf sebagaimana pada tahap kedua, namun pada tahap ini, pemerintah mulai memperluas pengawasannya. Untuk mencapai tujuannya ini, pada tahun 1948 M pemerintah mulai memperluas atau memperbanyak daerah-daerah wakaf. Dengan kebijakan ini diharapkan lembaga-lembaga wakaf yang disebar di daerah tersebut dapat merekrut pegawai wakaf untuk mengurusi masjid dan orang-orang yang membutuhkan.

Pada saat yang sama, masyarakat terutama dari golongan tua/tokoh masyarakat mendirikan Dewan Wakaf Agama yang dipimpin pertama kali oleh Syekh Abdullah Jabir Al-Shobah. Dewan tersebut didirikan pertama kali pada bulan Januari tahun 1949 dan mengalami penyempurnaan sampai tiga kali yaitu pada tahun 1951 M, 1956 M, dan 1957 M.

Departemen secara bertahap mulai memperluas pengawasan terhadap masjid-masjid yang ada pada saat itu di mana pengawasan serta pengelolaan masjid masih diserahkan kepada para imam dan muadzin masjid tersebut. Awalnya sulit, dikarenakan banyak pertentangan bahkan perlawanan dari kalangan para imam dan muazin. Mereka menganggap negatif kebijakan tersebut. Pada akhirnya dengan metode dialog, para imam dan muadzin bersedia menyerahkan pengaturan masjid kepada dewan kepengurusan masjid serta dana wakafnya. Setelah adanya perdamaian dengan para imam dan muadzin tersebut, pemerintah mulai mengadakan perencanaan untuk pengaturan perawatan dan pemulihan masjid, mulai membangun masjid-masjid yang rusak dan mengatur gaji para imam dan muadzin masjid. Ini adalah masa baru dalam Islam di mana terdapat kepercayaan manajemen syariat kepada pemerintahan di Kuwait.

Perlu diketahui, pada masa ini terutama pada 05/04/1951, pemerintah mengeluarkan peraturan terhadap badan-badan wakaf untuk menggunakan peraturan wakaf pada madzhab Maliki. Sebelum peraturan tersebut dikeluarkan, peraturan wakaf di Kuwait mengacu kepada empat madzhab besar dalam Islam sehingga muncul berbagai perbedaan di antara badan-badan wakaf di Kuwait terutama badan-badan wakaf swasta. Dengan adanya aturan penyatuan madzhab ini diharapkan dapat mempermudah pengaturan wakaf di Negara tersebut. Peraturan inilah yang pada akhirnya dijadikan UU wakaf sampai sekarang.

4) Tahap keempat (tahap pelayanan (1962 - 1990 M)) Pada masa inilah Kuwait mendeklarasikan kemerdekaannya. Dengan adanya deklarasi tersebut, perkembangan wakaf pun mengalami pembaharuan yaitu dibentuknya sebuah departemen di bawah kementrian di Kuwait yang bertugas khusus untuk mengurusi wakaf. Departemen ini didirikan pada tanggal 17 Januari 1962 M, kemudian pada tanggal 1965/10/25 diubah menjadi kementrian wakaf dan urusan Islam. Kementrian ini mempunyai beberapa tanggung jawab dan di antaranya adalah kepengurusan wakaf. Kementrian ini memberikan kepercayaan atas wakaf terhadap lembaga khusus yang berada di dalam kementrian yang mengurusi wakaf sampai bulan Juli, kemudian lembaga ini diubah menjadi lembaga independen yang dipimpin oleh wakil asisten kementrian.

5) Tahap kelima (tahap invasi Irak (1990 - 1991 M)) Tahap ini adalah tahap tersulit di dalam tubuh pemerintahan Kuwait terutama bagian wakaf. Pemerintah berusaha keras untuk melindungi dokumen-dokumen wakaf dari pemusnahan akibat invasi Irak ke Kuwait. Selain itu, pemerintah Kuwait bekerjasama dengan pusat studi Kuwait untuk menganalisa dokumen-dokumen tersebut serta menggali sejarah perwakafan Kuwait mulai dari zaman kuno.

6) Tahap keenam (pasca pembebasan (1991-1993 M)) Tahap ini disebut pula dengan tahap pembenahan. Hal tersebut dikarenakan pemerintah Kuwait mulai mengadakan pembenahan terhadap sistem birokrasi terutama pada bidang wakaf yang sempat berantakan akibat invasi Irak. Selain pembenahan di sektor kelembagaan, pemerintah Kuwait mulai membangun sumber daya manusia termasuk di dalamnya adalah pada hal perwakafan. Pada tahap ini, manajemen wakaf di lapangan menjadi menurun karena konsentrasi pemerintah adalah pada pembenahan sumber daya manusianya.

Kuwait sebagai salah satu negara yang pengelolaan wakafnya sangat berhasil. Pemerintah Kuwait pada tahun 1993 membentuk Kuwait Awqaf Public Foundation (KAPF) untuk mendorong perkembangan wakaf dan mempromosikan perbaikan ekonomi dan sosial-kemasyarakatan serta meringankan orang miskin dari berbagai kesulitan yang dialaminya. KAPF melakukan berbagai upaya untuk mewujudkan manajemen wakaf yang efektif. 
Dari segi pemanfaatan, KAPF menggunakan wakaf untuk pelayanan publik, mengembangkan sosioekonomi komunitas, terutama di daerah yang kurang maju. Hasilnya bisa kita lihat dari beberapa proyek wakaf yang telah berjalan dengan sukses seperti proyek industri skala kecil dan menengah serta proyek untuk studi mengenai perkembangan Islam.

7) Fase ketujuh (sekjend Wakaf (per 1993 M))

Untuk meningkatkan pelayanan serta pengabdian terhadap masyarakat terutama pada bidang wakaf, pemerintah Kuwait membentuk sekretaris Jenderal wakaf dan dikeluarkannya peraturan pemerintah pertanggal 13 Nopember 1993 M tentang wakaf.

3.1.3.Macam-macam wakaf di Kuwait

1) Wakaf untuk masjid

Ada ciri khas dari wakaf masjid di negara Kuwait. Negara ini sudah membiasakan wakaf untuk masjid sejak dahulu kala. Wakaf untuk masjid baik untuk pembangunan, renovasi atau lainnya itu seperti amalan untuk mendekatkan diri pada Allah. Tidak berhenti pada sisi fisik saja, pembangunan masjid diimbangi dengan dorongan untuk mengajak kaum muslimin melaksanakan shalat jumah di masjid. Bahkan, mereka yang memiliki kekayaan lebih akan mewakafkan sepertiga hartanya untuk masjid.

Masjid yang dibangun bukan saja di daerahnya sendiri. Wakaf untuk masjid bahkan untuk membangun masjid yang berada di luar daerah si wakif. Tujuannya, agar masjid bisa dijadikan tempat yang enak untuk para ahli ibadah, orang shaleh, para pelajar, dan sebagai sarana untuk menegakkan kalimat Allah. Mereka juga mewakafkan tanah dan pekarangan mereka sebagai inventaris produktif yang nantinya dimanfaatkan untuk kemaslahatan masjid. Mereka berlombalomba memakmurkan rumah Allah sebagai sarana untuk mendekatkan diri kepada Allah. Sedangkan, wakaf untuk masjid itu kemudian dialokasikan untuk gaji dan sarana imam, muadzin, membangun dan merenovasi masjid, biaya madrasah tahfidzul quran, makanan buka puasa, dan lain-lain.

2) Wakaf makanan

Wakaf ini disediakan bagi mereka yang membutuhkan atau kelaparan. Makanan ini juga disediakan bagi golongan miskin dan fakir. Pada waktu-waktu tertentu, pembagian makanan ini akan semakin banyak seperti hari raya dan bulan ramadan. Wakaf juga diperuntukkan untuk kurban pada hari raya.

3) Wakaf Publik. Wakaf ini diperuntukkan untuk membantu fakir miskin, orang yang butuh, dan membangun lembaga-lembaga keislaman dan sosial lainnya.

4) Wakaf kesehatan. Wakaf ini diperuntukkan untuk membangun rumah sakit, biaya perawatan dan lembaga kesehatan lainnya semisal apotek dan penelitian

5) Wakaf untuk pelajar

Wakaf ini diperuntukkan untuk membangun lembaga pendidikan, percetakan dan dibagikan secara cuma-cuma ke berbagai negara yang membutuhkan, beasiswa ke luar negeri baik untuk studi keislaman atau ilmu umum lainnya.

6) Wakaf air

Sebagai negara padang pasir, Kuwait sangat membutuhkan air. Wakaf air ini dialokasikan untuk membangun sumber-sumber air di tempat umum dan tempat strategis lainnya. Dana itu juga dialirkan ke berbagai negara Islam yang membutuhkannya

7) Wakaf Al Qur'an

8) Wakaf investasi. Wakaf ini diperuntukkan untuk membiayai perawatan dan pengembangan wakaf.

9) Wakaf untuk perawatan Jenazah. Wakaf ini diperuntukkan untuk biaya memandikan, mengkafani dan mengubur jenazah.

\subsubsection{Tata kelola wakaf di Kuwait}

Di negara Kuwait fungsi regulator perwakafan dijalankan oleh kementerian Wakaf (Ministry of Awqaf), akan tetapi lembaga pemerintah yang berwenang mengurus aset-aset wakaf ialah Kuwait Awqaf Public Foundation (KAPF) yang terbentuk sejak tahun 1993 dan diberlakukannya UU lembaga wakaf untuk pengelolaan wakaf yang effisien. UU ini memberikan platform yang diperlukan untuk semua hal yang berkaitan dengan urusan wakaf termasuk transparansi manajemen dana dan investasi dana sesuai ketentuan dan kondisi yang ditentukan oleh para pendiri (Khalil, Ibrahim Ahmad, Ali, Shaiban, 2014).

Awqaf Public Foundation (KAPF) didirikan oleh Keputusan Emir Kuwait: Amire Ordinance No. 257 tahun 1993 yang dikeluarkan pada 13 November 1993. Keputusan ini memberi KAPF status badan pemerintahan dengan otonomi relatif dalam pengambilan keputusan untuk mengatur dan mengelola sistem pengelolaan wakaf secara internal dan eksternal. Bagian pertama dari UU ini dengan jelas menyatakan bahwa semua fungsi Wakaf dari Kementerian Wakaf dan Urusan Islam telah ditransfer kepada KAPF (Ahmad, Mahadi, Syed Khalid Rashid, et al., 2015). Misi utama dari KAPF adalah untuk mengkonsolidasikan konsep wakaf sebagai mekanisme pembangunan di masyarakat dan mengaktifkan perannya dalam mencapai tujuan para pendiri disamping untuk memperkuat peradaban Islam kontemporer (Dahi, 1998 dalam Khalil, Ibrahim Ahmad, Ali, Shaiban, 2014).

Tanggung jawab utama dari KAPF adalah mendorong munculnya wakaf baru, mengatur dan mengalokasikan dana untuk kegiatan dan investasi aset. Selain itu, KAPF berkoordinasi dengan pemerintah dan badan-badan non-pemerintah untuk 
pembentukan proyek-proyek wakaf yang sesuai syariah untuk mencapai tujuan wakaf. Koordinasi ini termasuk khusus mengelola dana khusus di sektor wakaf, lembaga regional untuk pengembangan wakaf dan pengelolaan wakaf keluarga. Pasal 10 dari Keputusan tersebut mewajibkan Dewan Wakaf Awqaf dari KAPF untuk memasukkan anggota dari Komite yang berbeda berda, yaitu Komite Syariah, Komite Proyek Wakaf dan Komite Eksekutif (Al Busharah, 2012 dalam Khalil, Ibrahim Ahmad, Ali, Shaiban, 2014).

Gambar 1 memperlihatkan Struktur organisasi dari KAPF dimana terdapat empat departemen (Shariah and legal department, Audit and inspection department, Planning and technical consultan department, and Training and development department) serta tiga Deputy Secretary Generals yang berada dibawah Sekretaris Umum (The Secretary General) yang mengontrol mengontrol aktifitas dari 10 departemen fungsional untuk investasi, aset wakaf, serta masalah informasi dan keuangan.

Departemen pengembangan sumber daya KAPF bertanggung jawab untuk pengembangan sumber daya wakaf dan membuka cakrawala baru dalam diversifikasi cara dan lingkup wakaf serta untuk memastikan pertumbuhan asset wakaf. Departemen investasinya mengelola investasi aset wakaf guna memperluas basis pendapatan dengan menggunakan sumber daya wakaf yang tersedia dalam menghasilkan pendapatan investasi secara terus menerus dan tidak terputus. Hal ini berkontribusi pada peningkatan pesat wakaf di Kuwait.

The Kuwait Awqaf Public Foundation (KAPF) menerapkan sistem Tata Kelola Perusahaan yang elegan yang membantu memberikan hasil yang baik dari administrasi wakaf di Kuwait. Ini dilakukan melalui organ regulasi berikut: pemantauan yang diinduksi sendiri untuk berhati-hati terhadap hal hal yang dimurkai Allah; Pengaturan syariah dilakukan melalui komite Syariah. Pengawasan publik terhadap dana yang disalurkan dilakukan melalui kementrian wakaf yaitu pada Biro Audit Negara Kuwait dan auditor lainnya; adanya jaringan informasi yang sesuai memungkinkan pembayaran wakaf secara online, transparansi, membuat inquiri, memelihara data base yang digunakan untuk mengetahui semua kegiatan wakaf di Kuwait dan di luar Kuwait. KAPF juga diharuskan untuk menyiapkan laporan tahunan untuk semua pengeluaran dan pendapatannya, ini merupakan hal yang membantu terciptanya akuntabilitas dan transparansi wakaf (Ahmad, Mahadi; Rashid, et al., 2015).

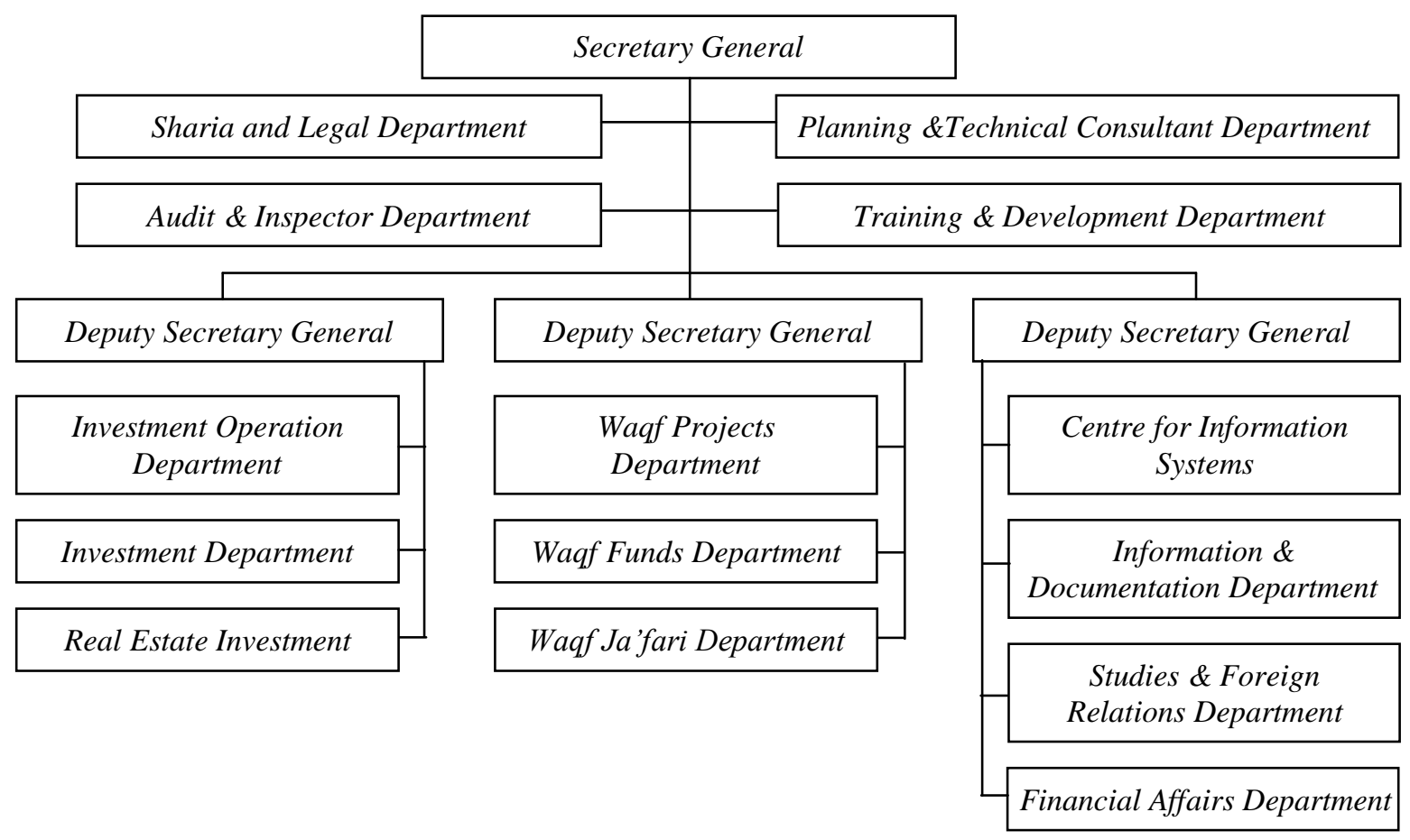

Gambar 1. Organization structure of kuwait awqaf public foundation

Tabel 1 berikut ini akan menggambarkan peningkatan pesat wakaf di Kuwait baik dilihat dari pendapatanya, pengembangan asset modal, maupun investasi dalam efek. Untuk menciptakan perubahan kualitatif dalam investasi dan pengembangan dana wakaf di Kuwait, unit investasi khusus telah didirikan untuk melaksanakan peran pengembangan dan investasi dana wakaf di berbagai bidang (Dahi, 1998 dalam Khalil, Ibrahim Ahmad, Ali, Shaiban (2014). 
Tabel 1. Perkembangan wakaf di Kuwait

\begin{tabular}{|l|c|c|}
\hline \multicolumn{1}{|c|}{ Kriteria } & $\begin{array}{c}\text { Tahun 1994 } \\
\text { (dalam USD) }\end{array}$ & $\begin{array}{c}\text { Tahun 2010 } \\
\text { (dalam USD) }\end{array}$ \\
\hline Pendapatan Wakaf & 30,13 juta & 110,82 juta \\
\hline $\begin{array}{l}\text { Pengembangan asset } \\
\text { modal }\end{array}$ & 371,1 juta & 759,2 juta \\
\hline $\begin{array}{l}\text { Nilai Pasar investasi } \\
\text { dalam efek }\end{array}$ & 46,58 juta & 975,93 juta \\
\hline
\end{tabular}

Sumber: Khalil, Ibrahim Ahmad, Ali, Shaiban (2014)

Dari Tabel 1 tersebut terlihat peningkatan pendapatan wakaf selama 16 tahun mencapai tiga kali lipat. Begitu juga dengan pengembangan asset modal mencapat peningkatan yang sangat signifikan yaitu dua kali lipat. Ini menunjukkan bahwa tujuan dari keberadaan wakaf itu tercapai dimana pokoknya tidak boleh hilang, bahkan asset modal wakaf terus mengalami peningkatan.

\subsubsection{Sumber keuangan wakaf di Kuwait}

Salah satu faktor utama dalam pelestarian asset wakaf adalah memastikan bahwa adanya pengembangan dan alokasi yang terus menerus dari sumber wakaf untuk investasi guna menghasilkan pendapatan sebagai dasar untuk memaksimalkan manfaat ekonomi dan sosial bagi stakeholder-nya. Artinya berbagai sumber pendapatan (kontribusi wakaf dan pendapatan investasi) yang telah diterapkan Kuwait merupakan salah satu yang sistem wakaf awal di negara Muslim. Berikut adalah kebijakan Kuwait terkait hal tersebut: (Khalil, Ibrahim Ahmad, Ali, Shaiban, 2014)

1) Mengalokasikan bagaian dari pendapatan wakaf untuk menambah aset wakaf;

2) Pendapatan yang dihasilkan dari aktifitas investasi untuk menyediakan pelayanan (services);

3) Adanya persetujuan Komite Perencanaa KAPF untuk seluruh warisan, pemberian, donasi berdasarkan prinsip dan kebijakan wakaf;

4) Adanya persetujuan Projects Committee KAPF atas pendapatan amal untuk investasi oleh sebagaimana yang di tetapkan oleh Kementerian wakaf.

Selain itu upaya KAPF dalam mendorong masyarakat untuk berwakaf pada lembaga wakaf telah berkontribusi pada pertumbuhan lembaga wakaf, di mana sampai dengan tahun1993 terdapat 90 lembaga wakaf, sampai 2005 terdapat 540 lembaga wakaf baru yang didaftarkan.

\subsubsection{Distribusi penghasilan wakaf di Kuwait}

KAPF dalam koordinasi dengan lembaga pemerintah dan asosiasi sosial memiliki peran yang signifikan dalam pengembangan masyarakat melalui pembagian pendapatan dari wakaf untuk kepentingan manusia untuk mencapai tujuan wakaf sesuai tujuan para pendirinya (A-Fadli 1998 dalam Khalil, Ibrahim Ahmad, Ali, Shaiban 2014). Peraturan KAPF dan kriteria untuk distribusi pendapatan wakaf yang meliputi:
1) Keterlibatan institusi swadaya masyarakat yang relevan dalam proses distribusi pendapatan wakaf agar terjadi proses kolektif;

2) Keterlibatan keluarga dan penduduk sebagai pemangku kepentingan dalam proses distribusi waqf untuk mengenalkan wakaf keluarga;

3) Distribusi pendapatan wakaf menjamin pemenuhan tujuan dan ketentuan para pendiri dan pencapaian tujuan wakaf dalam pengembangan masyarakat;

4) Menciptakan dan mengikuti mekanisme yang sesuai untuk mendistribusikan pendapatan wakaf untuk memastikan distribusi yang tepat.

Kuwait melalui layanan wakaf berbasis komunitas memberikan berbagai pelayanan yang meliputi:

1) Proyek wakaf untuk pembangunan kesehatan: Proyek ini didirikan untuk memberikan dukungan bagi layanan kesehatan dengan mendukung proyek dan program untuk meningkatkan standar layanan kesehatan masyarakat.Selama 16 tahun, dukungan pendanaan proyek jenis ini meningkat secara signifikan dari KD104.9 juta pada tahun 1995 menjadi KD1, 926 juta pada tahun 2011.

2) Proyek bantuan pendidikan: Proyek ini khusus mensponsori siswa yang membutuhkan untuk biaya sekolah dan biaya pendidikan lainnya. Sejak tahun 1997alokasi dana wakaf untuk proyek ini meningkat secara substansial dari KD92.8 ribuan pada tahun 1997 menjadi KD450.9 ribuan pada tahun 2011

3) Pembangunan sosial dan proyek ilmiah: Proyek amal ini dibentuk oleh KPAF untuk mendukung danmeningkatkan upaya pemerintah dan swasta untuk meningkatkan layanan ilmiah, pembangunan budaya dan sosial melalui kombinasi kegiatan wakaf dan proyek yang didanai pemerintah. Sejak berlangsungnya proyek ini, alokasi dana wakaf untuk proyek ini meningkat secara substansial dari KD 160.9 juta pada tahun 1995 ke KD 3,912,5 juta pada tahun 2011.

\subsection{Peran wanita dalam wakaf di Kuwait}

Wanita memiliki peran penting dan efektif dalam wakaf produktif. Sebagian dari mereka telah menyumbangkan kepemilikan pribadi dan benda hipotik yang pengaruhnya jelas dalam perkembangan wakaf di Kuwait. Kesadaran beragama ini sudah mentradisi dari zaman dahulu. Tujuannya hanya ingin dekat dengan Allah.

Sebagian dari para wanita, ada yang membangun sebuah masjid dekat rumahnya. Ia mewakafkan dua rumahnya dekat masjid. Yang satu menjadi sekolah Al-Quran dan satunya menjadi rumah Imamnya. Dan beberapa tahun ini, Kementrian Kuwait mengadakan acara seminar yang dihadiri para wanita. Acara ini bertujuan untuk lebih meningkatkan peran wanita dalam meningkatkan wakaf di Kuwait. 
Melihat data statisitik yang dirilis oleh departemen wakaf Kuwait menunjukkan peran wanita dalam peningkatan wakaf cukup signifikan. berikut fakta yang tercatat:

1) Dibidang wakaf produktif, jumlah perempuan Kuwait yang mewakafkan (165), meningkat 50\%;

2) Di bidang wakaf Mesjid, jumlah mereka (11) $7 \%$ dari jumlah umum;

3) Di bidang wakaf keluarga: Jumlah perempuan (27) yang mewakili $38 \%$ dari total orang orang yang berwakaf;

4) Di bidang Wakaf umum: wakaf wanita (21) yang mewakili $46 \%$ dari total.

Jumlah wakif perempuan (224) menjadi jumlah yang tidak bisa disepelekan. Jumlah itu sekitar $38 \%$ dari wakif di Kuwait. Rasio yang tinggi ini menunjukkan kontribusi nyata dan efektif perempuan Kuwait di Wakaf Yayasan Islam.

\subsection{Perbandingan pengelolaan wakaf produktif di Indonesia dan Kuwait}

Di Indonesia untuk mengembangkan dan memajukan perwakafan di bentuk suatu lembaga independen berdasarkan Undang-Undang Nomor 41 tahun 2004 tentang Wakaf, lembaga tersebut adalah Badan Wakaf Indonesai (BWI). BWI dibentuk pada tanggal 13 Juli 2007 melalui Kepres no 75 th 2007. BWI dibentuk bukan untuk mengambil alih aset-aset wakaf yang selama ini dikelola oleh nazhir (pengelola aset wakaf) yang sudah ada. BWI hadir untuk membina nazhir agar aset wakaf dikelola lebih baik dan lebih produktif sehingga bisa memberikan manfaat lebih besar kepada masyarakat, baik dalam bentuk pelayanan sosial, pemberdayaan ekonomi, maupun pembangunan infrastruktur publik.

Sebagaimana esensi dari wakaf adalah berkembang, maka nazhir harus mampu mengembangkan harta wakaf, sehingga berhubungan langsung dengan upaya pemecahan masalah-masalah sosial dan kemanusiaan, seperti pengentasan kemiskinan dan pemberdayaan ekonomi umat. Selama ini di Indonesia masih banyak harta wakaf terutama tanah yang masih terlantar tidak bisa dikembangkan karena keterbatasan daalam mengembangkan baik dana maupun manajerial. Berdasarkan data Direktorat Pemberdayaan Wakaf Kementerian Agama RI tertanggal Maret 2016 di Indonesia terdapat luas tanah wakaf 4.359.443.170 $\mathrm{M}^{2}$, namun masih banyak yang terbengkalai dan belum optimal memberikan manfaat bagi pengentasan kemiskinan dan pemberdayaan ekonomoi.

Meskipun demikian saat ini tidak sedikit lembaga ataupun institusi swadaya masyarakat yang sudah mulai mengelola wakaf menjadi lebih produktif. Di antara kesuksesan wakaf produktif telah dijelaskan dalam banyak penelitian seperti kemajuan zakat produktif disumatera barat yang dilakukan oleh lembaga lembaga swadaya masyarakat yang sudah mengelola berbagai sarana sarana bisnis (Rozalinda, 2016). Salah satu contoh kesuksesan pengembangan wakaf di bidang pendidikan adalah wakaf produktif pondok Pesantren Gontor, di mana dalam rangka mengembangkan aset wakaf dibentuklah unit-unit usaha dalam bentuk Koperasi Pondok Pesantren. Hasil pengembangan harta wakaf kemudian digunakan untuk mengembangkan pendidikan dan pengajaran, gedung, serta kesejahteraan keluarga pondok (Faza, et al., 2016). Serta masih banyak contoh pengelolaan wakaf produktif lainnya di Indonesia.

\section{Simpulan}

Wakaf merupakan satu solusi yang diberikan oleh Islam untuk mengatasi masalah sosial dan ekonomi. Sejarah sejak zaman Rasulullah, khulafah Ar Rasyidin sampai zaman sekarang telah membuktikan bahwa wakaf mampu memainkan peran penting dalam mewujudkan kesejahteraan masyarakat dan menjadi solusi dari berbagai permasalah ekonomi dan sosial. Berbagai penerapan wakaf di beberapa negara bisa menjadi contoh bagi Indonesia dalam mengoptimalkan peran wakaf untuk mengatasi masalah yang dihadapi ummat Isalam saat ini. Salah satu contoh praktek wakaf produktif yang diterapkan oleh negara Kuwait. Beberapa hal yang dapat disimpulkan dari pengelolaan wakaf produktif di Kuwait adalah sebagai berikut:

1) Perkembangan wakaf di Kuwait sudah melewati sejarah yang sangat panjang. Sejak masa sebelum tahun 1921 wakaf sudah dikelola secara produktif, terbukti dengan berbagai bentuk wakaf pada masa itu seperti wakaf toko, rumah, wakaf pohon (kelapa), perikanan dan lain-lain;

2) Saat ini wakaf di Kuwait dikelola dengan konsep tata kelola yang sudah baik dan maju, melalui keberadaan Kuwait Awqaf Public Foundation (KAPF);

3) Tata kelola yang baik terhadap zakat berdampak positif terhadap peningkatan pendapatan dari wakaf serta pengembangan barang modal yang terus bertambah. Hal ini tentunya sangat sejalan dengan tujuan keberadaan wakaf itu sendiri;

4) Kuwait memiliki sistem distribusi yang baik dengan melibatkan masyarakat dan keluarga.

Partisipasi perempuan dalam perkembangan wakaf di Kuwait patut menjadi motivasi bagi perempuan Indonesia untuk berleomba lomba dalam kebaikan (fastabiqul khairat). 


\section{Referensi}

Al Quran Al Karim

Al Hadist

Ahmad, Mahadi, Syed Khalid Rashid,etc, (2015). The Legal And Regulatory Framework For Zakah And Waqf Administration In Kuwait: Lessons For Nigerian Zakah And Waqf Institutions. International Journal of Business, Economics and Law, Vol. 7, Issue 4 Aug 2015 .ISSN 22891552

Ali, Muhammad Daud.(2012). Sistem Ekonomi Islam Zakat dan Wakaf.Jakarta: Universitas Indonesia Press.

Anshori, Abdul Ghofur. 2005. Hukum dan Praktik Perwakafan di Indonesia Yogyakarta: Pilar Media

Aula, Muhammad Abbas. (2012). Pemberdayaan Umat Melalui Lembaga Wakaf. Jurnal Al Awqaf, Volume 2 Nomor 2, Juli 2012.

Faza, Muhammad Iqbal. Azidni Rafiqo. Aminah Oktarina (2016) Model Pengembangan Wakaf Produktif Pondok Modern Darussalam Gontor Ponorogo. Jurnal Al Awqaf, Volume 9 No 2 Juli 2016.

Huda, Nurul, Nova Rini dkk. (2017). Problems, Solutions and Strategies Priority for Waqf in Indonesia. Journal of Economic Cooperation and Development, 38, 1 (2017), 29-54

Khalil, Ibrahim Ahmed, Yunus Ali, Mohammad Shaiban (2014) Waqf Fund Management In Kuwait And Egypt: Can Malaysia Learns From Their Experiences. Proceeding of the International Conference on Masjid, Zakat and Waqf (IMAF 2014) (e-ISBN 978-967-13087-1-4). 1-2 December 2014, Kuala Lumpur, Malaysia.

Khosyi'ah, Siah. 2010. Wakaf dan Hibah: Perspektif Ulama Fiqh dan Perkembangannya di Indonesia. Bandung: Pustaka Setia.

Lita, Helza Nova (2017). Pemanfatan Dana Tabungan Haji untuk Pengembangan Wakaf Produktif (Studi Perbandingan Pembangunan Commercial Building di atas Tanah Wakaf - Gedung Imata Wakaf di Kuala Lumpur). Jurnal Al Awqaf, Volume 10 No 2 Desember 2017.

Najib Tuty A., dkk (2006). Wakaf, Tuhan dan Agenda Kemanusiaan. Jakarta: Center fo The Study of Religion and culture UIN, Jakarta.
Rahman, Khalilur (2015). Sejarah Perkembangan Wakaf di Kuwait. Bahan Kuliah Pasca Sarjana IAIN Ibrahimy dengan dosen pengampu Dr. KH. Nawawi Thabrani, M.Ag.

Rozalinda.(2016).Management Wakaf Produktif di Sumatera Barat. Jurnal Al Awqaf, Volume 9 No 2 Juli 2016.

Rusydiana, Aam S dan Abrista Devi. (2017). Analisis Pengelolaan Dana Wakaf Uang di Indonesia; Pendekatan Metode Analitic Network Porcess (ANP). Jurnal Al Awqaf, Volume $10 \mathrm{No} 2$ Desember 2017.

Sadeq, Abul Hasan.M (2002). Waqf, Perpetual Charity and Poverty Alleviation. International Journal of Sosial Economic, Vol 29 No1/2, 2002.

Shaikh,Salman Ahmed , Abdul Ghafar Ismail, Muhammad Hakimi Mohd Shafiai. (2017). Application of waqf for social and development finance. ISRA International Journal of Islamic finance. Vol 9,No 1 tahun2017.pp 5-14.

Badan Pusat Statistik, Jumlah penduduk miskin Indonesia, www.bps.go.id diakses tanggal 29 Maret 2018

Bank Indonesia. (2016). Wakaf: Pengaturan dan Tata kelola yang Efektif.

Direktorat Pemberdayaan Wakaf dan Direktorat Jenderal Bimbingan Masyarakat Islam.(2008) Paradigma Baru Wakaf di Indonesia, Jakarta:

Undang -Undang Republik Indonesia No 41 Tahun 2004 Tentang Wakaf

Pesentase Umat Islam Indonesia Menjadi 85\%, republika.co.id diakses tanggal 29 maret 2018

Ustman bin Affan: Makin Kaya Raya Setelah Sedekahkan Sumur. www.kompasiana. com/bangun_lubis/ustman-bin-affan-makinkaya-raya-setelah-sedekahkan-sumur

Badan Wakaf Indonesia (BWI) : Potensi Wakaf Di Indonesia Mencapai 180 Triliyun, http://mysharing.co diakses tanggal 2 april 2017

Kuwait. https://id.wikipedia.org/wiki/Kuwait, diakses tanggal 2 Juli 2018

Profil Negara Kuwait. https://www.kemlu.go.id/ kuwaitcity/id/Pages/Profil-Negara-Kuwait.aspx diakses tanggal 3 Juli 2018 